\title{
第24回秋季学術大会 一般研究発表予稿集
}

1. EPIを用いたT1值計測

Measurement of T1 value using EPI sequence.

福井医科大学医学部附属病院 放射㟫部 ○松田 囊、指江 浩之、小室 裕苒

【目的】今回我々の施設に1shot EPIが可能な装置が革入された。本装置を用いれば様々な機能検查かできる と期待している。ところでそれら機能挨查の定盖解析の際に、スライス断面のT1值測定が必要な場合がある。 そこでEPIを用いることで実時間以内にT1值の測定か可能かを検討した。

【方法】硫酸銅溶液のT1值を、IR_EPI法と通常のIR法とで測定し比較検封した。

【結果·考察】1shot EPIを用いると約10\%の紫差で硫酸銅浚液のT1值を測定できた。実際の測定時間は非常

に短くなり検榃時間内に可能となる。しかしEPIは磁埼の不均一に敏感であるために適応部位は限られる。

また原理的に長いTE成分が合まれるために、T2の短い物質の測定に関しては誤差が增すと考えられる。この 点に関してはさらに検討をおこなっていく予定である。さらに現在は空間分解能を血力落としてT2の長い 成分を洋入させないようにしているため関心領域が選びにくくなっており、測定時間をあまり延長させずに 空間分解能をあげる工夫も考えたい。

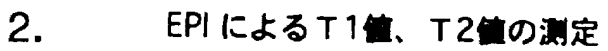

Measurement of $\mathrm{T} 1, \mathrm{~T} 2$ value by Echo Planer Imaging

(目的)

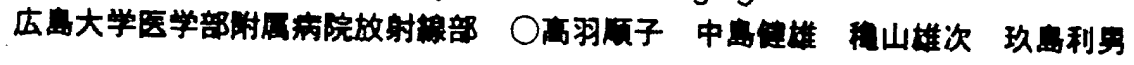

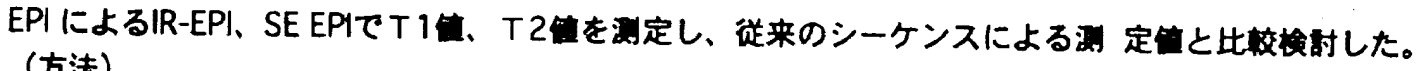

(方法)

T1管: IR、Fast IR ( ET: 8-32)、IR EPI (shot: 1-32)

T2年 : SE, Fast SE(ET: 8-32)、SE EPI (shot : 1-32)

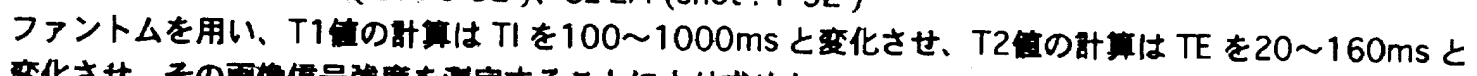

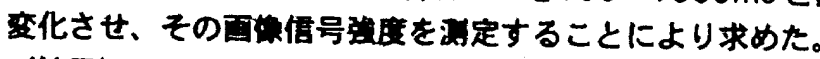

（结果）

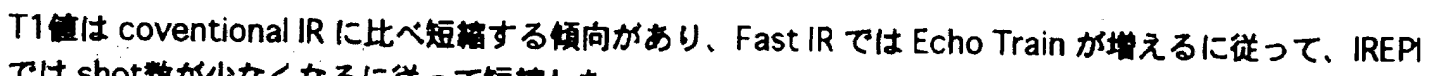

では shot数が少なくなるに従って短虽した。

T2管は coventional SE に比へ延長する便向があ、Echo Trainや shot数による野は少なかった。

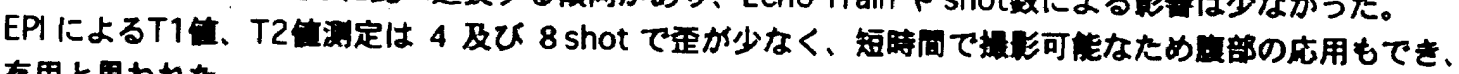

有用と思われた。

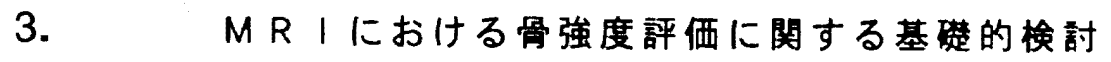

Study of Bone Strength Evaluation by MRI

厚生中央病院放射線科 $\bigcirc$ 南部武幸城西放射線専門学校 中谷儀一郎星名利文

【目的】現在骨㙁量の测定は、扮もにX線を用いる方法と超音波を用いる方法とがある。MRIではミネラル より信号を得ることができないため、評洒の方法として試みられることがほとんどなかった。そこで今回は、 骨塩量の娍少に伴ら各楥和時間の変化を調べることでの骨強度評価を娭討したので報告する。

【方法】(1) $\mathrm{CaCO}_{3} 、$ ラード、ゼラチンからなるファントムを自作し、3 要素を各々変化させ合計 25 本の試料と した。そのファントムの摱像扰よび信号の測定を行い、通常の T1、T2、T2*值とChemical Fat Suppression 法 により、脂肪信号の抑制された状態での T1、T2值を求めた。

(2)政床例として、過去にX線 SPA方式の骨密度测定装置にて骨塩量の測定を行った方から、30名を対象者 とし、踵骨を測定部位としてファントムと同粎に测定を行い、それぞれの值を求めた。

【結果】(1) T1 值と脂肪抑制 T1 值はミネラル量の減少に応じて延長していた。また脂肪濃度が增加すると $\mathrm{T} 1$ 值は規則的に短摍していた。ミネラルと T2*值の関係はほぼ比例を示した。T2值と脂肪抑制 $\mathrm{T} 2$ 値は有意な 変化がみられなかった。

(2)臨床例でもファントム実験とほぼ同じ結果が得られ、よいもので骨塩量との相関係数は 0.62 以上となった。 【考察】T2*值は実験結果とその釉和原理から骨強度そのものが信号に反映していることが示唆される。 